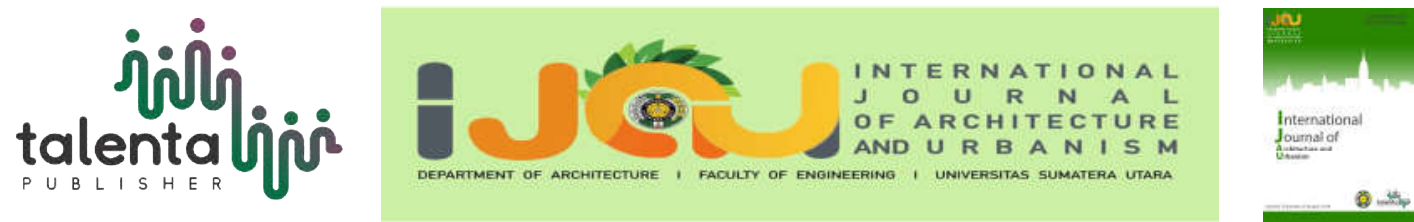

\title{
Bus Terminal Design in Transit Oriented Development Area (TOD) in Pinang Baris
}

\author{
Achmad Delianur Nasution ${ }^{1}$, Rochmad Siddhiqie ${ }^{1}$ \\ ${ }^{I}$ Department of Architecture, Universitas Sumatera Utara, Medan, Indonesia
}

\begin{abstract}
According to the development plan of MEBIDANG-RO, Pinang Baris has been stated as TOD Area. Bus Terminal will be the transit center within the area and have direct integration to buildings surround it. Issues that appeared solved with utilizing the land that will be allocated as circulation area to prevent crossing circulation between transportation and passengers, contemporary architecture theme will be applied, and the building shape will be following the circulation plan that has made before, Therefore, the design of Pinang Baris Bus Terminal would fulfill the needs of users in TOD Pinang Baris.
\end{abstract}

Keyword: bus terminal, TOD, contemporary architecture, Pinang Baris

\section{Introduction}

As one of the biggest city in Indonesia, Medan should improve their self to give proper service for both of its current people and visitors, domestic or international. Transit Oriented Development, as one of the solutions for improving the qualities of a city, should be implemented in Medan, regarding the rise of the population itself that affected the usage of private vehicles, that disturbing the street, and decreasing the quality of pedestrian, also the use of public transportation itself.

Based on MEBIDANG-RO (Medan-Binjai-Serdang Bedagai- Karo) Development Plan, Pinang Baris, Medan, was areal that functioned as a TOD (Transit Oriented Development) Area which focused on Bus Transportation as its main mode to reach the areal. With this condition, it is needed to design an areal that having a direct orientation with Bus Transit Terminal, and if we referring to this site, the integral transit building will be Pinang Baris Bus Terminal. A Terminal as a hub of transportation helps increasing street service operational. With the presence of terminal inside of the areal, which its activities are uplifting and dropping the passengers back and forth, would help the opportunities of Pinang Baris, having a significant growth on its economic aspect, also adding more values inside of the areal itself.

\footnotetext{
*Corresponding author at: Department of Architecture, Faculty of Engineering, Universitas Sumatera Utara,

Jalan Perpustakaan Gedung J07, Medan 20155, Indonesia

E-mail address: aan.nasution@gmail.com
} 
The main issues that appeared in designing Bus Terminal are crossed circulation between passengers and transportation, then creating the transit building as the new landmark in Medan. With this understanding, there are several things to be concerned, about designing transit building, which are, how we could prevent crossed circulation between Transportation and Passengers, Also how we can implement contemporary architecture style in Transit Oriented Development Based area, in order to make the Bus Terminal standing as a landmark of Medan, especially in Pinang Baris.

\section{Literature Review}

Transit Oriented Development (TOD) is an urban development approach that aims to address the number of private transportation usage and change the mindset of people to switch to using public transport and public facility that can support pedestrians to explore the region [1]. This Basic concept has transit points that not only serve as a place to lift and drop the passengers but as a place that provides few functions of the building where various urban activities take place in the aspects of the economy, education, services and others. Terminal is a transportation facility for uplifting and dropping goods, also operating the arrival and departure of passengers, and public transportation, as form of hub, which connects between the people and the transportation mode [2].

Contemporary in a concept of Architecture could be defined as "a progressive, versatile, flexible, and innovative design, by the form and its masses, material selection and process, asymmetrical, also the technology used will affect the style of architecture". Contemporary design will show its audience an edgy style, and result from a brand new and freshen up the norms of the design world itself. It will appear to combine various style, such as modern contemporary, classical contemporary, eclectic, and many other things.

\section{Methodology}

The design begins with designing the Masterplan of Pinang Baris area using Transit Oriented Development (TOD) approaching, where the location was chosen because it has a magnificent potential on the land around Pinang Baris thus it is Integrates with Bus Terminal. The Terminal that Integrated within Pinang Baris became one of the main focus of designing, the implementation of Transit Oriented Development (TOD) concept to attract public interest to use public transportation modes and walk more to building functions designed there in the areal [3].

Seeing the importance of having proper Bus Terminal within the area, that integrated with various building function in its surrounding, becoming the concern to be solved by design. Because in the end the Bus Terminal itself will generate activities and inviting 
people to come to the area. Bus Terminal design itself, based on the chosen theme will be formed in Contemporary Architecture style, also using data, requirements, standards, and needs of Bus Terminal that mention within the governmental regulation about public facilities, and based on literary which are Data Architects and Time Saver Standards books.

\section{Result and Discussion}

\subsection{Land allocation analysis}

In Pinang Baris Transit Oriented Development area, Terminal is a transit building that became the center of the region. Traditional Markets, Shopping Mall and Transit Hotel located in the area are functions that supporting the areal shaped as a center of activity so that people are more encouraged to use public transportation in fulfilling their daily needs. Because the land that you want to create must be walkable and vehicle free, so the integration between the terminal and other buildings should be comfortable and secure for its users., From this concept, then we formed the Master Plan TOD Pinang Baris, where the design itself provides proper pedestrian quality for users of the terminal and other buildings, such as on ground pedestrian network, and having skicross that connects each building, which let users in the second level of building, also having direct integration to another building in the area (Figure 1).

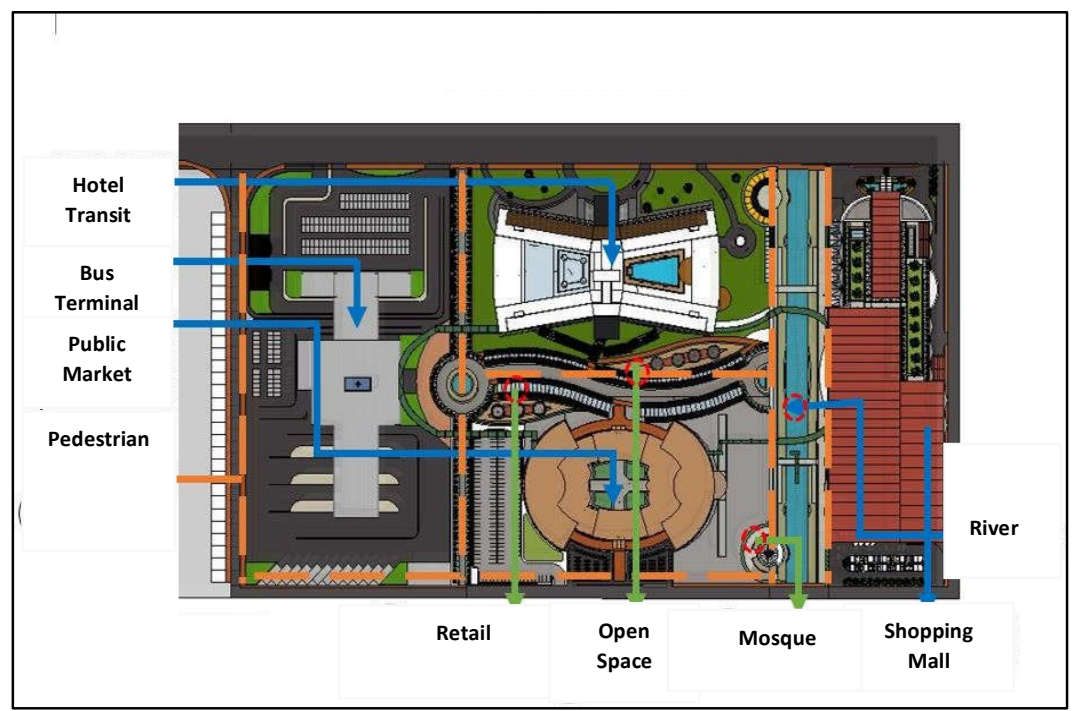

Figure 1. Designated Masterplan of Transit Oriented Development in Pinang Baris

Regarding the usage of Pinang Baris Terminal as the main entrance of Western Medan, affect the design of façade itself, to make a grande and lux appearances, the roof and wall structure merged unified as one and made the construction as part of the façade itself. The material used as the coverages are metal sheets and tempered glass. The usage of this, aim to create a sleek and clean look towards the terminal building. With this contemporary design approachment, it is hoped that one day, this building will be a landmark in Medan (Figure 2). 
Groundplan design, formed after setting a proper circulation of transportation within the areal. There is a building separation, happened to prevent a crossing between public transportation and pedestrian. These two masses, later on, connected by the second-floor, which will be used as the commercial area of the terminal.

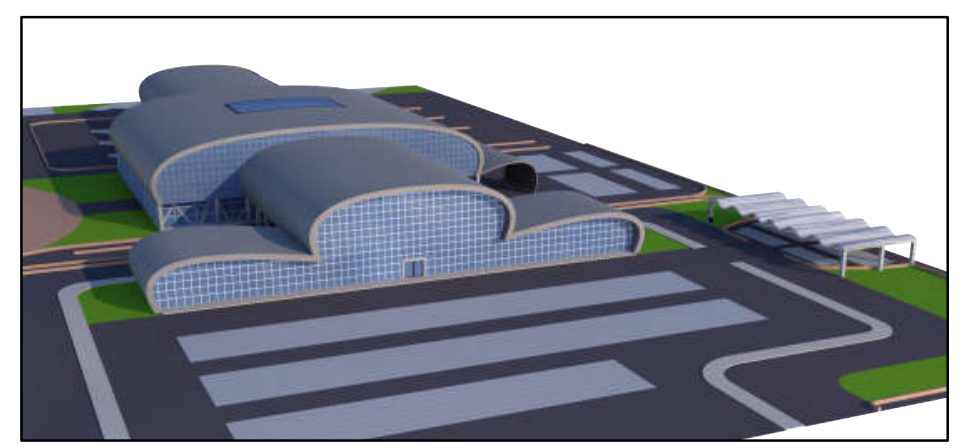

Figure 2. The Form and Mass Concept of Pinang Baris Bus Terminal

There are three circulation zones inside the areal, which private cars and motorcycles in the front areal, public transportation in the middle side of the areal, and the backside are areal for busses that lift and drop passengers from and to another city also provinces. The first floor is used as an arrival lobby for passengers, also the departure lobby for passengers. There are also retails, restaurant, and café in this level. The second floor, is an administrative areal for the terminal, also waiting room areal for passengers before departing by bus. There are also different commercial areal here. So in total, the building consists of 2 stories and 12,250 $\mathrm{m}^{2}$ total building area (Figure 3).

The façade of this terminal, design by using contemporary architecture style, where using the roof structure as part of the whole building coverages. The material used for the façade are metal sheets and tempered glass. There is not much ornament applied despite the glass accent itself, this decision made to make visitors visually focused on the curved that made as a building coverage, and to emphasize the contemporary style within the building (Figure 4). 


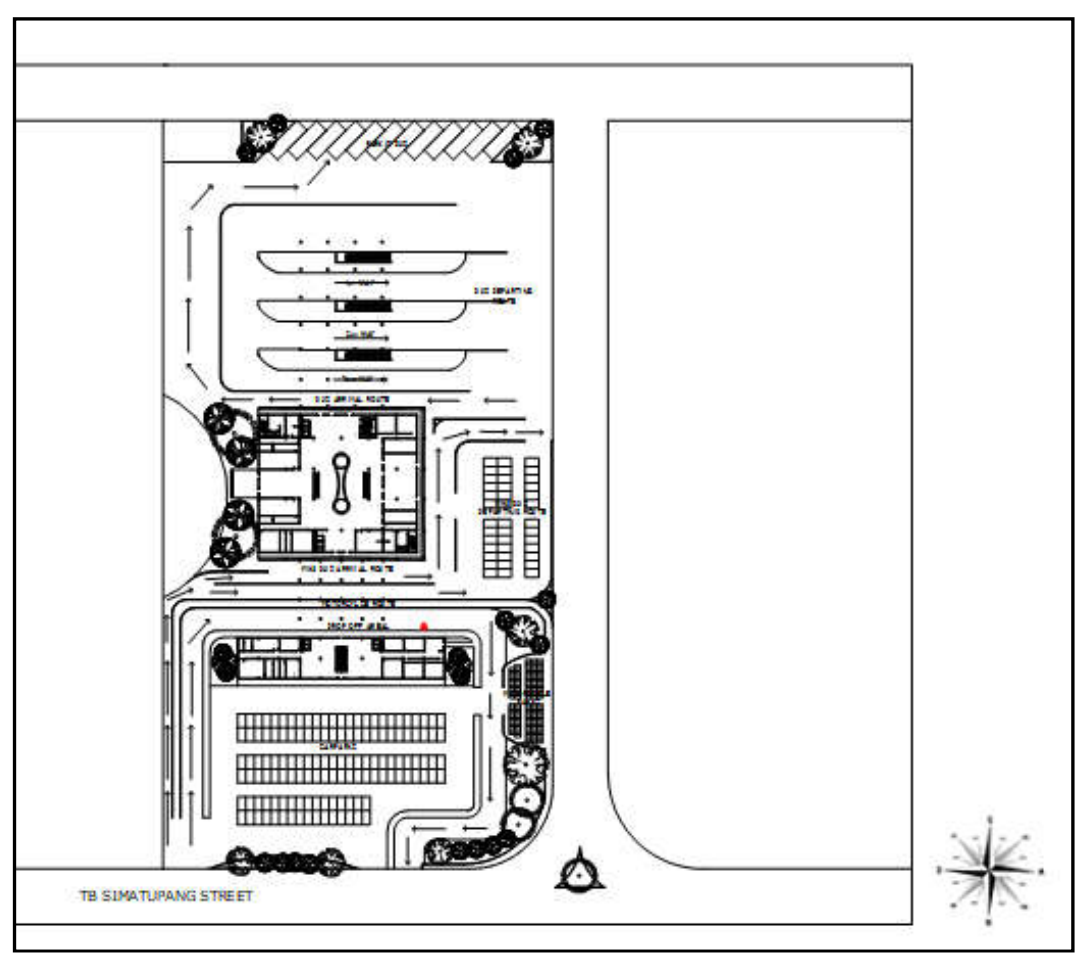

Figure 3. Ground Plan of Pinang Baris Bus Terminal

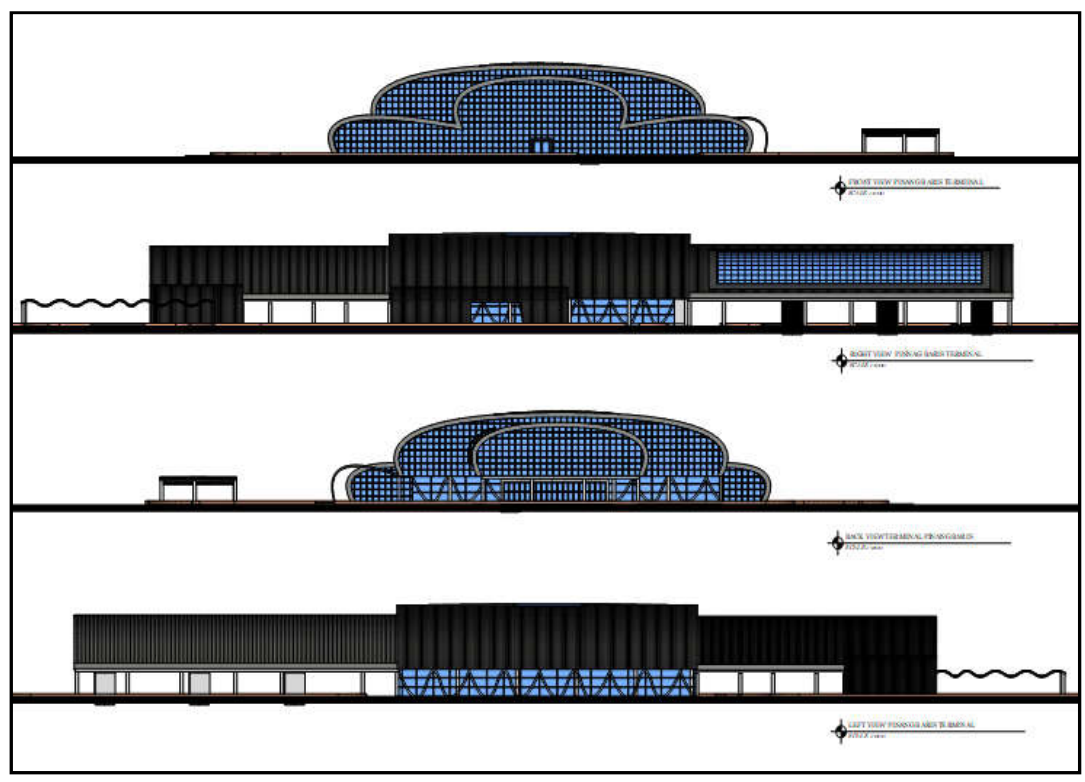

Figure 4. Lists of View of Pinang Baris Bus Terminal to Understand the Usage of Material Within the Building

The structured used within this building is barrel vault space frame, It will cover the whole building, and will use as both roof and the walls of the building also the curve structure is exposed inside the building, the structure itself has the width of 1 meter. For the lower structure, this building using a reinforced concrete frame to hold the weight of the big structure from the barrel vault space frame (Figure 5). 


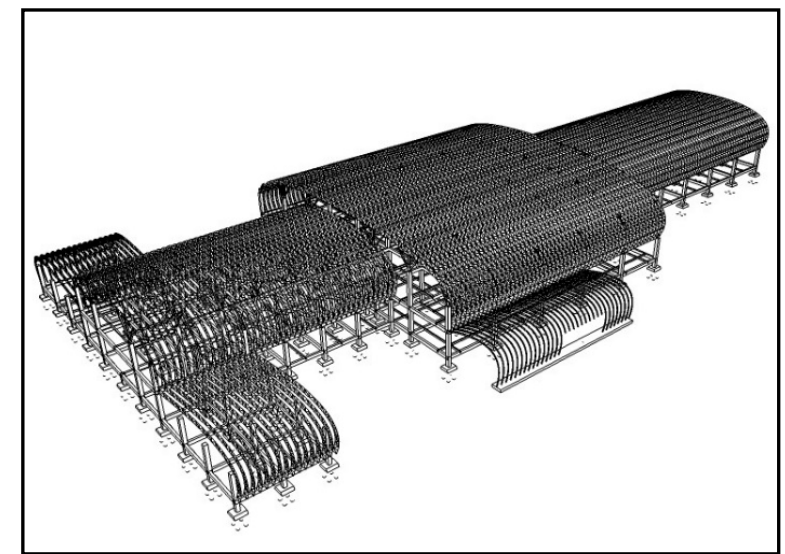

Figure 5. Structure Perspective of Pinang Baris Bus Terminal

\section{Conclusion}

Designing Bus Terminal in Transit Oriented Development areal (in this case Pinang Baris areal) will help to improve the qualities and to add the values of this land. With the presence of transit functioned building, it will help increase the number of visitors to Pinang Baris areal, which also means, emerging opportunities from its economic side to be increased. Despite, the presence of terminal building is urgent when we talk about TOD Areal, and Pinang Baris Bus Terminal will also integrate to another building in its surrounding so that it will decrease the use of the private vehicle within the areal.

Circulation be the main concern, for designing terminal, on how we prevent crossing circulation between pedestrian/passengers and the public transportation, by creating the circulation plan first before designing the indoor spatial plan, may give a comfortable, safe, and walkable environment to its passengers, and clarity of transportation route within the terminal area, beside the circulation, structure also be the concern of this design. Because we aim to make a landmark terminal building, then we decide to use contemporary architecture approachment to designing the façade and the structure, which we used barrel vault space frame as the construction theme to give a lux and grande look to the terminal, it is needed, because Pinang Baris Bus Terminal is an entrance from the western side of Medan, so the building should be representative.

\section{Acknowledgment}

This research is part of the requirement to obtain a bachelor's degree in Architecture Department, Universitas Sumatera Utara.

\section{REFERENCES}

[1] John S Niles and Lisa Callaghan Jerram, From buses to BRT: Case Studies of incremental BRT projects in North America. San José: Mineta Transportation Institute, College of Business, San José State University, 2010.

[2] Joseph De Chiara and John Hancock Callender(eds), Time-saver standards for building 
types. New York: McGraw-Hill, 1990.

[3] Peter Calthorpe, The next American metropolis: Ecology, community, and the American dream. New York: Princeton architectural press, 1993. 